\title{
IMPLEMENTASI PEMURIDAN KONTEKSTUAL DALAM MENANAMKAN NILAI- NILAI PENDIDIKAN KARAKTER BAGI ANAK USIA DINI
}

\author{
Oleh : \\ Vivin Parinding. Nirm : 1020175364 \\ Jurusan Pendidikan Agama Kristen, IAKN Toraja \\ E-mail : vivinparinding06@gmail.com
}

\section{A. ABSTRAK}

Anak usia dini adalah anak yang berada pada rentang umur antara 0-6 tahun. Masa ini sering juga disebut dengan istilah "golden age" atau masa emas, dimana anak akan mengalami perkembangan secara cepat, baik dari segi fisik, psikis, maupun karakter setiap anak. Pada masa ini karakter setiap anak akan di proses, baik itu melalui lingkungan dimana anak tersebut berada maupun keluarga dimana anak mendapatkan pendidikan untuk pertama kalinya. Dengan demikian, pada masa ini merupakan waktu yang paling baik untuk menanamkan nilai-nilai karakter pada anak. Melalui pemuridan kontekstual yang dilakukan dapat membantu menanamkan nilai-nilai karakter dalam diri setiap anak. Anak membutuhkan pendidikan untuk menumbuhkan karakter yang positif dalam diri mereka.

\section{B. PENDAHULUAN}

Pembentukan karakter anak tidaklah lahir begitu saja, ada proses yang dilewatinya sehingga proses tersebut pun menjadi karakter yang melekat dalam diri seorang anak. ${ }^{1}$ Setiap individu memiliki karakter yang unik dan hal tersebut yang membuat seseorang berbeda dengan yang lainnya. Mendapatkannya pun tidaklah begitu saja, namun harus melewati beberapa proses sejak masih kanak-kanak. Usia dini adalah usia yang sangat menentukan dalam pembentukan karakter dan kepribadian anak. ${ }^{2}$ Peranan keluarga sangatlah mempengaruhi pembentukan karakter anak, mengetahui

\footnotetext{
${ }^{1}$ Ditha Prasanti dan Dinda Rakhma Fitriani, "Pembentukan Karakter Anak Usia Dini: Keluarga, Sekolah, dan Komunitas?," Jurnal Obsesi, Vol. 2 No. 1 (2018): 14

${ }^{2}$ Husnuzziadatul Khairi, “Karakteristik Perkembangan Anak Usia DIni Dari 0-6 Tahun,” Jurnal Warna, Vol.2 No. 2 (Desember 2018): 15
} 
bahwa keluarga merupakan salah satu tempat anak mendapatkan pendidikan untuk pertama kalinya. Teman bermain dan lingkungan dimana anak berada pun menjadi salah satu yang ikut serta mempengaruhi pembentukan karakter anak.

Pendidikan karakter bagi anak usia dini dimaksudkan untuk menanamkan nilainilai kebaikan supaya dapat menjadi kebiasaan ketika kelak dewasa atau pada jenjang pendidikan selanjutnya. ${ }^{3}$ Pendidikan anak pada usia dini sangat perlu mendapatkan perhatian untuk menerapkan pendidikan karakter demi masa depan anak-anak. Pendidikan karakter diyakini sebagai aspek dalam meningkatkan sumber daya manusia (SDM) karena turut menentukan kemajuan suatu bangsa ${ }^{4}$ Pada masa ini anak belum memiliki pengaruh yang negatif dari luar. Anak diibaratkan sebagai selembar kertas putih yang masih kosong dan belum diisi. Sehingga baik orang tua maupun tenaga pendidik akan jauh lebih mudah untuk membimbing anak-anak, terlebih dalam menanamkan nilainilai karakter pada setiap anak. Usia dini adalah masa terbaik untuk mengembangkan potensi dan kemandirian anak usia dini. ${ }^{5}$ Melihat bahwa masa ini adalah masa-masa emas bagi seorang anak (golden age) untuk mengembangkan setiap potensi yang ada pada dirinya, terlebih mengembangkan dan membentuk karakter dalam dirinya.

Dengan pemuridan kontekstual penanaman nilai-nilai karakter kepada anak-anak diharapkan agar kedepannya anak-anak akan tumbuh dan menjadi manusia yang berkepribadian baik sehingga ia dapat menjadi teladan dan bermanfaat bagi dirinya, masyarakat sekitar, maupun bermanfaat bagi bangsa dan Negara.

Berdasarkan pembahasan diatas, maka dapat ditarik sebuah rumusan masalah penelitian yaitu : Bagaimana implementasi pemuridan kontekstual dalam menanamkan nilai-nilai karakteristik bagi anak usia dini?

\section{TUJUAN}

Tujuan dari penelitian ini adalah untuk mengetahui Implementasi Pemuridan Kontekstual Dalam Menanamkan Nilai-Nilai Karakteristik Bagi Anak Usia Dini.

\footnotetext{
${ }^{3}$ Eka Sapti Cahyaningrum, Sudaryanti, Nurtanio Agus Purwanto, “Pengembangan Nilai-Nilai Karakter Anak Usia Dini Melalui Pembiasaan Dan Keteladanan," Vol. 6, Edisi 2 (Desember 2017): 204

${ }^{4}$ Devi Sofa Nur Hidayah dan Cahniyo Wijaya Kuswanto, "Implementasi Pendidikan Karakter Anak Usia Dini Melalui Metode Bermain Peran Usia 5-6 Tahun Di Taman Kanak-Kanak An-Nahl Bandar Lampung," PAUD Lectura: Jurnal Pendidikan Anak Usia Dini, Vol 3 No 1 (Oktober 2019): 2

${ }^{5}$ Daviq Chairisyah, "Analisis Kemandirian Anak Usia Dini," PAUD Lectura: Jurnal Pendidikan Anak Usia Dini, Vol 3 No 1 (Oktober 2019): 89
} 


\section{MANFAAT}

Adapun manfaat dari penulisan ini ialah agar anak khususnya anak usia dini mendapatkan pendidikan karakter sejak dini dan para pendidik dan orang tua dapat menanamkan nilai-nilai pendidikan karakter demi masa depan anak-anak.

\section{E. PEMBAHASAN}

\section{Anak usia dini}

Anak usia dini adalah anak yang berada pada rentan usia 0-6 tahun (Undangundang Sidiknas tahun 2003). Anak usia dini adalah kelompok anak yang berada dalam proses pertumbuhan dan perkembangan yang unik. ${ }^{6}$ Anak usia dini merupakan individu yang berbeda, unik, dan memiliki karakteristik tersendiri sesuai dengan tahapan usianya. Usia ini merupakan usia ketika anak mengalami pertumbuhan dan perkembangan yang pesat. Pada masa ini, stimulasi seluruh aspek perkembangan memiliki peranan penting untuk tugas perkembangan selanjutnya. ${ }^{7}$

Masa usia dini merupakan masa kecil ketika anak memiliki kekhasan dalam bertingkah laku. Segala bentuk aktivitas dan tingkah laku yang ditunjukkan seorang anak pada dasarnya merupakan fitrah. Sebab, masa usia dini adalah masa perkembangan dan pertumbuhan yang akan membentuk kepribadiannya ketika dewasa. Seorang anak belum mengerti apakah yang ia lakukan itu berbahaya atau tidak, bermanfaat atau merugikan, serta benar maupun salah. Hal yang terpenting bagi mereka adalah ia merasa senang dan nyaman dalam melakukannya. Oleh karena itu, sudah menjadi tugas orang tua dan dan pendidikan untuk membimbing dan mengarahkan anak dalam beraktivitas supaya yang dilakukannya tersebut dapat bermanfaat bagi dirinya sehingga nantinya dapat membentuk kepribadian yang baik. ${ }^{8}$

\section{Pemuridan}

\footnotetext{
${ }^{6}$ Mansur, Pendidikan Anak Usia Dini Dalam Islam, (Yogyakarta: Pustaka Belajar, 2005), 88

${ }^{7}$ H. E. Mulyasa, Manajemen Paud, (Bandung: Remaja Rosda Karya, 2012), 20

${ }^{8}$ Husnuzziadatul Khairi, “Karakteristik Perkembangan Anak Usia DIni Dari 0-6 Tahun,” Jurnal Warna, Vol.2 No. 2 (Desember 2018): 17
} 
Pemuridan adalah hubungan antara guru dan murid didasarkan pada pola Kristus dan kehidupan-Nya yang diajarkan kepada murid-Nya. ${ }^{9}$ Secara umum pemuridan berfungsi memperlengkapi setiap individu untuk berakar dan bertumbuh di dalam Kristus untuk memenuhi kebutuhannya. Seseorang memberi diri untuk dimuridkan agar ia senantiasa bertekun dalam mengajaran, dalam persekutuan dan di dalam doa (Kis. 2:42). Pemuridan merupakan Amanat Agung Tuhan Yesus (Mat. 28:18-20). Melalui pemuridan karakter setiap orang akan dibentuk dan meningkatkan pengetahuan dan ketaannya terhadap kebenaran Firman Tuhan.

\section{Pemuridan Kontekstual}

Pemuridan ini memakai nama Kelompok Tumbuh Bersama Kontekstual (KTBK) atau Contextual Bible Group (CBG). ${ }^{10}$ Pemuridan kontekstual adalah model pemuridan yang menggunakan konteks sebagai pertimbangan utama. ${ }^{11}$ Pemuridan kontekstual memiliki karakteristik yang bersifat Alkitabiah. Hal ini menunjukan bahwa Alkitab merupakan pusat dari pembelajaran yang dilkukan dalam pemuridan kontekstual. ${ }^{12}$ Pemuridan kontekstual ini bertujuan agar anak-anak dapat bertumbuh sesuai dengan pemahamanan kebenenaran isi Alkitab dan menghargai nilai-nilai kebangsaan sehingga melahirkan anak-anak yang berprestasi, berakhlak dan berkepribadian yang baik.

\section{Nilai-nilai Pendidikan Karakter}

Nilai-nilai pendidikan karakter yang wajib diterapkan dan ditanamkan pada anak usia dini sebagai berikut :

1. Religius. Sikap dan perilaku yang patuh dalam melaksanakan ajaran agama yang dianutnya, toleran terhadap pelaksanaan ibadah agama lain, dan hidup rukun dengan pemeluk agama lain.

\footnotetext{
${ }^{9}$ Daniel Fajar Panuntun dan Eunike Paramita, “Hubungan Pembelajaran Alkitab Terhadap Nilai-Nilai Hidup Berbangsa Dalam Pemuridan Kontekstual (Kelompok Tumbuh Bersama Kontekstual)," Jurnal Gamaliel : Teologi Praktika, Vol 1 No 2 (September 2019): 106

${ }^{10}$ Yulianti dan Kezia Yemima, "Model Pemuridan Konseling Bagi Alumnus Perguruan Tinggi Lulusan Baru (Fresh Graduaten) Yang Mengingkari Panggilan Pelayanan," Jurnal Gamaliel: Teologi Praktika, Vol 1 No 1 (Maret 2019 ): 31

${ }^{11}$ T Haryono dan Daniel Fajar Panuntun, “Andil Pemuridan Kontekstual Yesus Kepada Petrus Yakobus Dan Yohanes Terhadap Keterbukaan Konseling Mahasiswa Pada Masa Kini'” Jurnal Gamaliel: Teologi Praktika, Vol 1 No 1 (Maret 2019): 17

12 Daniel Fajar Panuntun dan Eunike Paramita, "Hubungan Pembelajaran Alkitab Terhadap Nilai-Nilai Hidup Berbangsa Dalam Pemuridan Kontekstual (Kelompok Tumbuh Bersama Kontekstual)," Jurnal Gamaliel : Teologi Praktika, Vol 1 No 2 (September 2019): 106
} 
2. Jujur. Perilaku yang didasarkan pada upaya menjadian dirinya sebagai orang yang selalu dapat dipercaya, baik dalam perkataan, tindakan dan pekerjaan.

3. Toleransi. Sikap tindakan yang menghargai perbedaan agama, suku, etnis, pendapat, sikap dan tindakan orang lain yang berbeda dari dirinya.

4. Disiplin. Tindakan yang menunjukkan perilaku tertib dan patuh pada berbagai ketentuan dan peraturan.

5. Kerja keras. Perilaku yang menunjukkan upaya sungguh-sungguh dalam mengatasi berbagai hambatan belajar dan tugas, serta menyelesaikan tugas dengan sebaik-baiknya.

6. Kreatif. Berpikir dan melakukan sesuatu untuk menghasilkan cara atau hasil baru dari sesuatu yang telah dimiliki.

7. Mandiri. Sikap dan perilaku yang tidak mudah bergantung pada orang lain dan menyelesaikan tugas-tugas.

8. Demokratis. Cara berpikir, bersikap dan bertindak yang menilai sama hak dan kewajiban dirinya dan orang lain.

9. Menghargai prestasi, sikap dan tindakan yang mendorong dirinya untuk menghasilkan sesuatu yang berguna bagi masyarakat, dan mengakui serta menghormati keberhasilan orang lain.

10. Bersahabat atau komunikatif, tindakan yang memperlihatkan rasa senang berbicara, bergaul dan bekerja sama dengan orang lain.

11. Cinta damai, sikap, perkataan dan tindakan yang menyebabkan orang lain merasa senang dan aman atas kehadiran dirinya.

12. Gemar membaca, kebiasaan menyediakan waktu untuk membaca berbagai bacaan yang memberikan kebajikan bagi dirinya.

13. Peduli lingkungan. Sikap dan tindakan yang selalu berupaya mencegah kerusakan pada lingkungan alam sekitarnya, dan mengembangkan upayaupaya untuk memperbaiki kerusakan alam yang sudah terjadi.

14. Peduli sosial. Sikap dan tindakan yang selalu ingin memberi bantuan pada orang lain dan masyarakat yang membutuhkan 
15. Tanggung jawab. Sikap dan perilaku seseorang untuk melaksanakan tugas dan kewajibannya, yang seharusnya dilakukan terhadap diri sendiri, masyarakat, lingkungan (alam, sosial, dan budaya) Negara dan Tuhan Yang maha Esa. ${ }^{13}$

\section{F. Kesimpulan dan Saran}

\section{Kesimpulan}

Dari keseluruhan pembahasan diatas dapat ditarik kesimpulan bahwa anak-anak pada usia dini memerlukan perhatian khusus dan pertumbuhan dan perkembangannya, khususnya pada pertumbuhan kepribadian atau karakter. Pendidikan karakter sangat baik diajarkan pada masa-masa ini, karena masa ini adalah masa dimana anak akan mengembangkan segala potensi yang ada pada dirinya. Dengan pemuridan kontekstual membantu untuk menanamkan nilai-nilai pendidikan karakter pada anak agar kelak tumbuh menjadi anak yang beraklak baik.

\section{Saran}

Karena pembentuka karakter dimulai usia dini, maka dukungan dan perhatian dari orang tua maupun pendidik sangat diperlukan untuk membantu tumbuh kembang anak dalam menanamkan nilai-nilai pendidikan karakter pada anak. Keluarga sebagai tempat anak mendapatkan pendidikan pertama, haruslah lebih memberikan perhatian dan dukungan berupa waktu kepada anak, agar setiap didikan yang diberikan akan tumbuh dengan baik dalam diri anak.

\footnotetext{
${ }^{13}$ Eka Sapti Cahyaningrum, Sudaryanti, Nurtanio Agus Purwanto, "Pengembangan Nilai-Nilai Karakter Anak Usia Dini Melalui Pembiasaan Dan Keteladanan," Vol. 6, Edisi 2 (Desember 2017): 208-209
} 


\section{Daftar Pusataka}

Prasanti , Ditha dan Dinda Rakhma Fitriani. "Pembentukan Karakter Anak Usia Dini: Keluarga, Sekolah, dan Komunitas?,” Jurnal Obsesi, Vol. 2 No. 1 (2018)

Khairi, Husnuzziadatul, "Karakteristik Perkembangan Anak Usia DIni Dari 0-6 Tahun,” Jurnal Warna, Vol.2 No. 2 (Desember 2018)

Cahyaningrum, Eka Sapti, Sudaryanti, Nurtanio Agus Purwanto. "Pengembangan Nilai-

Nilai Karakter Anak Usia Dini Melalui Pembiasaan Dan Keteladanan,” Vol. 6, Edisi 2 (Desember 2017)

Hidayah, Devi Sofa Nur dan Cahniyo Wijaya Kuswanto. "Implementasi Pendidikan

Karakter Anak Usia Dini Melalui Metode Bermain Peran Usia 5-6 Tahun Di Taman KanakKanak An-Nahl Bandar Lampung,” PAUD Lectura: Jurnal Pendidikan Anak Usia Dini, Vol 3 No 1 (Oktober 2019)

Chairisyah, Daviq. "Analisis Kemandirian Anak Usia Dini," PAUD Lectura: Jurnal Pendidikan Anak Usia Dini, Vol 3 No 1 (Oktober 2019)

Mansur. Pendidikan Anak Usia Dini Dalam Islam. Yogyakarta: Pustaka Belajar, 2005

Mulyasa, H. E. Manajemen Paud. Bandung: Remaja Rosda Karya, 2012

Panuntun, Daniel Fajar dan Eunike Paramita. "Hubungan Pembelajaran Alkitab Terhadap

Nilai-Nilai Hidup Berbangsa Dalam Pemuridan Kontekstual (Kelompok Tumbuh Bersama Kontekstual),” Jurnal Gamaliel : Teologi Praktika, Vol 1 No 2 (September 2019)

Haryono T dan Daniel Fajar Panuntun, "Andil Pemuridan Kontekstual Yesus Kepada

Petrus Yakobus Dan Yohanes Terhadap Keterbukaan Konseling Mahasiswa Pada Masa Kini'” Jurnal Gamaliel: Teologi Praktika, Vol 1 No 1 (Maret 2019)

Yulianti dan Kezia Yemima. "Model Pemuridan Konseling Bagi Alumnus Perguruan

Tinggi Lulusan Baru (Fresh Graduaten) Yang Mengingkari Panggilan Pelayanan,” Jurnal Gamaliel: Teologi Praktika, Vol 1 No 1 (Maret 2019) 